\title{
The Chinese in Southern Europe: Has urban regeneration addressed their new form of clustering?*
}

\author{
Giulio Verdini
}

University of Westminster. Department of Urban Planning and Transport

g.verdini@westminster.ac.uk

\section{Enrico Russo}

Xi'an Jiaotong-Liverpool University. Department of Urban Planning and Design enrico.russo.pi@gmail.com

\begin{abstract}
This paper attempts to analyse the particular features of Chinese clustering in two southern European cities and the urban regeneration responses employed in the decade 2005-2015: Prato in Italy and Santa Coloma de Gramenet in Spain, which are among the cities with the highest rate of Chinese in-migration within their respective countries. The main aim is to show which urban regeneration policies have been adopted in both contexts and to evaluate, in comparative terms, how they have addressed the two local Chinese communities. The paper will argue that their form of clustering, developed since the 1990s, has featured a certain degree of social segregation and tensions with local communities. On the other hand, they have become two dynamic urban nodes in supra-local business networks, possibly demanding new forms of engagement in the governance system. The results show that the urban regeneration policies in place have partially failed to acknowledge the changing nature of their form of clustering, with the risk to exacerbate existing conflicts and to prevent beneficial mutual collaborations.
\end{abstract}

Keywords: Chinese migration; clustering; urban regeneration; integration; Southern Europe

* This research entitled 'I hate Karl Marx. Chinese clustering impact on European cities and the challenge of planning' has been made possible by the generous contribution of Xi'an Jiaotong-Liverpool University, Research Development Fund (RDF 10-01-05). We would like to acknowledge the contribution of Riccardo Pecorario, Valentina Sardi, Martín Miralles Asensio, Anna Bahia, Clara Ortega, Elena Suarez, Maria Font Tarrason and Laura Font. The kind advice from Gladys Nieto, Joaquín Beltrán Antolín, Camilla Perrone and Matthew Cocks are also gratefully acknowledged alongside the insightful comments of the two anonymous reviewers. 
Resum. Els xinesos al sud d'Europa: la regeneració urbana ha tingut en compte les noves formes de comunitat?

Aquest treball analitza les característiques particulars de les comunitats xineses en dues ciutats del sud d'Europa i les propostes de regeneració urbana que s'han dut a terme en la dècada 2005-2015. Prato a Itàlia i Santa Coloma de Gramenet a Espanya es troben entre les ciutats amb major percentatge d'immigració xinesa en els seus respectius països. L'objectiu principal és mostrar quines polítiques de regeneració urbana s'han adoptat en els dos contextos i avaluar, en termes comparatius, com s'han dirigit a les dues comunitats xineses locals. L'article exposarà que la seva forma de comunitat, desenvolupada des dels anys noranta, ha comportat un cert grau de segregació social i de tensions amb les comunitats locals. D'altra banda, s'han convertit en dos nodes urbans dinàmics dins de les xarxes empresarials supralocals, que possiblement exigeixen noves formes de participació en el sistema de governança. Els resultats mostren que les polítiques de regeneració urbana en marxa han fallat parcialment a l'hora de reconèixer la naturalesa canviant de les seves comunitats, amb el risc d'exacerbar els conflictes existents i obstaculitzar col.laboracions beneficioses mútues.

Paraules clau: migració xinesa; comunitat; regeneració urbana; integració; Europa del sud

Resumen. Los chinos en el sur de Europa: ¿la regeneración urbana ha tomado en cuenta las nuevas formas de comunidad?

Este trabajo analiza las características particulares de las comunidades chinas en dos ciudades del sur de Europa y las propuestas de regeneración urbana que se han llevado a cabo en la década 2005-2015. Prato en Italia y Santa Coloma de Gramenet en España se encuentran entre las ciudades con mayor porcentaje de inmigración china en sus respectivos países. El objetivo principal es mostrar qué políticas de regeneración urbana se han adoptado en ambos contextos y evaluar, en términos comparativos, cómo se han dirigido a las dos comunidades chinas locales. El artículo expondrá que su forma de comunidad, desarrollada desde los años noventa, ha comportado un cierto grado de segregación social y de tensiones con las comunidades locales. Por otro lado, se han convertido en dos nodos urbanos dinámicos dentro de las redes empresariales supralocales, que posiblemente exijan nuevas formas de participación en el sistema de gobernanza. Los resultados muestran que las políticas de regeneración urbana en marcha han fallado parcialmente en reconocer la naturaleza cambiante de sus comunidades, con el riesgo de exacerbar los conflictos existentes y obstaculizar colaboraciones beneficiosas mutuas.

Palabras clave: migración china; comunidad; regeneración urbana; integración; Europa del sur

Résumé. Les Chinois en Europe du Sud: la régénération urbaine a-t-elle tenu compte des nouvelles formes de communautés?

Cet article tente d'analyser les particularités des communautés chinoises dans deux villes du sud de l'Europe et les propositions de régénération urbaine mises en œuvre dans la décennie 2005-2015 : Prato en Italie et Santa Coloma de Gramenet en Espagne comptent parmi les villes présentant le plus taux d'immigration chinoise le plus élevé dans leurs pays respectifs. L'objectif principal est de montrer quelles politiques de régénération urbaine ont été adoptées dans les deux contextes et d'évaluer, en termes comparatifs, comment elles ont tenu compte des deux communautés chinoises locales. L'article montrera comment leur forme de communauté, développée depuis les années 90, a comporté un certain 
degré de ségrégation sociale et de tensions avec les communautés locales. D'autre part, elles sont devenues deux noyaux urbains dynamiques dans les réseaux d'entreprises supra-locaux, exigeant peut-être de nouvelles formes d'engagement dans le système de gouvernance. Les résultats montrent que les politiques de régénération urbaine en place ont partiellement échoué à reconnaître la nature changeante de leurs communautés, avec le risque d'exacerber les conflits existants et d'empêcher des collaborations mutuelles bénéfiques.

Mots-clés: migration chinoise; communautés; régénération urbaine; intégration; Europe du Sud

\author{
Summary \\ 1. Introduction \\ 2. Chinese clustering in Europe \\ 3. Urban regeneration and social \\ sustainability \\ 4. A tale of two cities: Prato and Santa \\ Coloma de Gramenet (SCdG)
}

\title{
1. Introduction
}

Twenty years ago Friedman (1995) warned about the coming challenges for planners of rising international migration in Europe. Quoting the experience of Los Angeles, he drew attention to issues that were to become central in the debate within just a few years: the massive shift of population into some affordable residential neighbourhoods resulting in spatial segregation, the explosive demographic growth of old manufacturing inner city areas due to inbound extra-European migration and the challenge of social integration and urban regeneration associated to the new demand placed on social services. The migration of Chinese citizens into Europe has been one of the largest additions to the European population in recent years, increasingly growing in the South of Europe. Contrary to what had happened in previous decades during the Chinese diaspora in Southeast Asia, North America and Australia (Baldassar et al., 2015), they have not normally reproduced the traditional image of a Chinatown and, at the same time, they have not even recreated the same conditions of marginality that often tend to characterise ethnic neighbourhoods.

Taking the UK as an example, the situation of deprived neighbourhoods facing high rates of in-migration, urban decay and unemployment, tackled by urban regeneration policies (McCarthy, 2007), seems to contrast with the Chinese clustering, which features a conversely high rate of entrepreneurship and normally lower unemployment rate (Berthoud, 2000). As a matter of fact, it is not just a Chinese feature. The degree of success of "ethnic entrepreneurship", regardless of nationality, might be related to the degree of embeddedness of the local community in extended community networks (Sahin et al., 
2009). More precisely, by the effectiveness of their 'mixed embeddedness' both in social networks of immigrants and in the socio-economic and politicoinstitutional environment of the country of settlements (Kloosterman et al., 1999). This characteristic fits quite well with the Chinese case, suggesting the potential advantages of establishing connections within the widespread Chinese local communities in Europe, and therefore with China itself. This is because, contrary to other ethnic communities, China is not just a country exporting workforce but also a strategic economic and commercial partner for Western countries, which is impacting upon the future economic performances of local contexts.

These considerations have already been clearly pointed out by Kunzmann (2008) in his paper about the implications of the rise of China for the spatial development of the European metropolitan city-regions. As a matter of fact, while Chinese migrants have often been considered a source of local conflict, some studies confirm that, beyond certain anti-Chinese rhetoric arguments often fuelled by media, there are also evident advantages. This is the case of the textile district of Prato where Chinese firms have basically replaced an already declining business with a flourishing garment industry, which is internationally well connected (Dei Ottati, 2009). The pragmatic approach advocated by Kunzmann obviously collides with the daily challenge of managing ethnic communities: from the unfair competition determined by the spreading of informal economies, when not properly addressed, to the biased image often depicted by certain political parties for seeking easy consensus at the local level. In addition to that, the combined effect of the economic downturn of the last years and the severe constraints on public spending, particularly in Southern Europe, has often prevented implementing ad hoc public policies, with the result of setting the question of migration aside.

For this reason, the paper will be focused on the countries of 'late development' in Southern Europe where, traditionally, the welfare state has partially failed its universalistic mission, exacerbating the long-lasting problem of a labour market often characterised by informality, and thus decreasing the possibilities of integration (Mingione, 2009). The cases of Prato, in Italy, and Santa Coloma de Gramenet (SCdG), in Spain, can contribute to the understanding of the phenomenon in this specific part of Europe, an area of relatively recent foreign in-migration or 'lack of migratory experience' facing, very often for the first time, the challenge of diversity (Ribas-Mateos, 2004). With this scenario, the paper analyses the policy responses in the decade 2005-2015 of these two medium-sized cities in Southern Europe, outlining the impact of the particular spreading and clustering of Chinese migrants at the local level. The comparison will show a diverse approach in a range of policies from those more specifically addressing the issue of social integration to those more related to urban regeneration.

Therefore, this comparative study attempts primarily to demonstrate whether the set of integrated policies employed have adequately addressed the particular form of clustering in both contexts. This question derives also from the 
consideration that Chinese communities are increasingly diverse and endowed with a potentially rich relational resource, which can play an essential role in generating processes of mutual understanding (Healey, 1997). However, despite their demand to be considered fully integrated in the local community, there is risk of the government engaging with various stakeholders without distinguishing between actors (weak and powerful or established and emerging), as the efficacy of governance in 'securing community involvement and assisting social integration in complex urban regeneration programmes' is still open to discussion (Van Bortel et al., 2009). Thus, in consideration of the changing conditions of the new Chinatowns and the complexity of social articulation within an apparently homogenous community, the ultimate goal of this paper will be to understand whether the two cities are capable of responding effectively to more complex Chinese communities, thus achieving social sustainability.

\section{Chinese clustering in Europe}

Chinese migration into Europe is not new but, at the time of the explosion of the phenomenon in the 1990s, the changing nature of the migration process became apparent: new migrants came from different places of origin, with a different socio-economic background and were mainly searching for employment opportunities in these newly selected destinations across the continent (Pieke, 2002).

The traditional urban areas in the north of Europe, where most of the Chinese migrants have settled since the last century, such as London, Amsterdam, Manchester, Liverpool and Paris, have been replaced, in terms of main destinations and speed of growth, by new areas of transit or settlement both in Central-Eastern Europe and in Southern Europe. A monographic issue of International Migration (Vol. 41, no. 3), raised this issue already in 2003, providing a comprehensive picture of the phenomenon. Italy stood out for the size of Chinese migration, revealing the important role of the combination of reiterative regulatory gaps, at the national level, and new employment opportunities, at the local level, in attracting Chinese migrants at that time. The low density of Chinese competitors also played an important role in the expansion of the Chinese presence in their traditional main sectors of activity; namely, garment and shoes workshops, and catering (Ceccagno, 2003). Spain was another new rapidly growing area of opportunity: in the 1980s, in activities mainly related to restaurants and catering, due to the booming tourist sector, and, later on, in a larger variety of small family businesses (Nieto, 2003). Modern Chinese migration follows the general trend of the late twentieth century of migration to metropolitan areas of high income and attractive countries (Skeldon, 1997). They do not encounter any further anti-Chinese legislation 'forcing them into secluded occupational niches and living quarters such as Chinatowns' (Wong, 1988), but, like other international migration flows, they move towards Western global cities in need of unskilled workers in basic service sectors or in marginalised old manufacturing sectors (Castells, 1989). 
Consequently, even if the traditional 'exotic' paradigm of Chinatown has been gradually dismantled (Thunø, 2007), new forms of concentration have re-emerged since the 1990s. The Italian case of ethnic garment and leather niches is paradigmatic of this new distinctive trend. They were initially socially and economically isolated and mainly concentrated in a few areas including Prato and Milan and, later on, turned into a transnational entrepreneurship base, importing and selling manufactured goods from China (Ceccagno, 2007a). Similarly, newly emerging businesses involving the Chinese in Spain are no longer confined to dispersed activities such as catering. The case of Barcelona is symptomatic of this process. Due to the unsustainably high competition among Chinese restaurants associated with the increase in Chinese migrants, Chinese economic activities have been gradually diversified in the metropolitan area. Clusters of Chinese shops have appeared across the city and suburban productive textile enclaves have replaced old ones, as in the case of SCdG (Beltran Antolín, 2000). However, while the Chinese migration has been extensively studied, Chinese urban clusters in Europe remains an 'unknown world' (Beraha, 2012) due to the relative lack of communicative channels between local governments and Chinese communities (Briata, 2013). This has often given rise to a feeling of resentment or fear that constituted clear obstacles to the implementation of urban transformations (Verdini, 2011).

It is not the same everywhere in Europe. The case of the construction of a 'friendship' decorative Chinese arch in Liverpool (Baxter and Woodland, 2005), which is not surprisingly one of the UK cities with the largest amount of Chinese students in its University, and the opening in 2015 of the prestigious 'China Exchange', a cultural centre in the heart of Soho in London, bear witness to a different approach in dealing with a local Chinese presence surely different (and wealthier) from the one largely present in South Europe.

Nevertheless, Italy and Spain show many similarities. The pace of Chinese migration in recent years and the increasing concentration in certain areas have produced social tensions locally. At the same time, ethnographic research shows that Chinese communities in both contexts are increasingly diverse, express different voices, and are more or less inclined to engage locally with existing communities (Chen, 2013).

The acknowledgement of diversity, together with the improvement of local participation, has been identified by Susan Fainstein as a way by which a city can achieve equity (2010). Following this stream of reasoning, the understanding of whether or not the two cities presented in this paper have addressed this topic in their integrated urban regeneration policies will be central to understand whether they have achieved social sustainability.

\section{Urban regeneration and social sustainability}

Urban regeneration is 'a comprehensive and integrated vision and action which leads to the resolution of urban problems and which seeks to bring 
about a lasting improvement in the economic, physical, social and environmental condition of an area that has been subject to change' and should 'seek to ensure consensus through the fullest possible participation and cooperation of all stakeholders with a legitimate interest in the regeneration of an urban area' (Roberts, 2000: 17-18). As an activity rooted in practice, it has evolved across the decades, being once primarily focused on the improvement and transformation of the built environment and later more concerned with the nature of local decision-making and the engagement of local community (Tallon, 2010). Therefore, the nature of local governance is increasingly becoming essential to evaluate the achievement of sustainable regeneration as 'sustainability emphasises participatory decision-making and partnerships that can enhance the legitimacy of regeneration among local people' (Jones and Evans, 2008: 84).

Within the discourse of the just city, the relationship between decisionmaking and power relations between majorities and minorities have been framed within the theoretical boundary of communicative planning theory (Forester, 1989; Healey, 1997). Healey (1998) proposed communicative planning as an appropriate answer to the specific challenge faced by multicultural contexts, such as deliberation as a possible form of decision-making in planning practice. Despite several criticisms of the practical implementation of deliberative planning, multicultural milieus are places where marginalised groups, with limited material resources, 'could benefit from attempts to promote a fair and equal hearing for diverse voices in public affairs' (Umemoto and Igarashi, 2009: 40).

The emphasis on social learning and mutual interaction between different stakeholders (public vs. private; powerful vs. marginalised; etc.) implies the existence of suitable systems of governance and institutions capable of acknowledging and reinforcing existing relational resources. The way they function can either enhance or reduce spatial-social exclusion (Healey, 2003) and, therefore, public policy research should focus on:

- How formal government actions currently affect people in their everyday lives in neighbourhoods, and whether these actions contribute to or detract from the reinforcement of exclusionary processes;

- What forms of governance exist, both formal and informal, which ones really make a difference to people's quality of life in their living places, and who gets access to them;

- What relational resources already exist and could provide a basis for sustainable improvements to the quality of neighbourhood life.

In the following sections, the policy response of two medium-sized cities, facing the challenge of a multicultural milieu, will be introduced. The aforementioned points will be used to evaluate the social sustainability of the policy responses of the two cities in light of their particular form of clustering. 


\section{A tale of two cities: Prato and Santa Coloma de Gramenet (SCdG)}

The research work on Prato and SCdG has been carried out in two phases: the systematic review of planning and policies related to social integration and urban regeneration of the two selected 'Chinese neighbourhoods'; and open-end interviews with local officers of both municipalities. The in-depth interviews have been conducted and recorded in Prato and SCdG. The main questions were related to the understanding of the spatial and social policies in place, adopted by different administrative sectors, to regenerate areas of migration considered problematic or worth urban interventions and the acknowledgment and the support of urban diversity. The following comparative presentation of the two cities will be supported by both quantitative and qualitative data derived from local statistics and from the interviews.

The choice of Prato and SCdG is based on evidence regarding the local importance of the Chinese migratory phenomenon. Chinese migrants are the most numerous local ethnic group in both cases, with these two locations having among the highest concentration of Chinese in their respective countries (in the Spanish case, this is the combination of SCdG and the neighbouring municipality of Badalona). Based on municipal statistical data, by the end of 2011, migrants living in Prato represented $16 \%$ of the total population (more than 29,500 out of 184,885 ) and $24.3 \%$ in SCdG (almost 30,000 out of 122,952). There were 13,056 Chinese migrants in Prato, representing $6.9 \%$ of the total population and $43.3 \%$ of the foreign-born population, with 4,798 Chinese migrants in SCdG, representing 3.9\% and $16.1 \%$, respectively. Prato and SCdG belong to two dense and industrialised metropolitan areas: the Piana Firenze-Prato-Pistoia with almost 1.5 million people and the Comarca Barcelonés, with almost 2.2 million people. Besides these numbers, there are other similarities such as the problem of cohabitation between Chinese and local people, the measures employed in both cases to reduce the risk of social conflict and establish dialogue with the Chinese community, and the high level of spatial segregation of Chinese neighbourhoods.

Chinese migration in Prato is concentrated along the via Pistoiese in Macrolotto Zero, the core of the industrial textile district from the 1950s to the 1970s, on the west side of the historic centre (Fig. 1). From an historical point of view, this neighbourhood grew quickly in the absence of a strict general plan. It combined residential and industrial areas, thus responding to the functional needs of the flourishing specialised family enterprises; a typical example of the districts of the so-called 'Third Italy' (Bagnasco, 1977). Prato has been considered the archetype of the Italian districts, both for its economic success (Becattini, 2001), but also for the several urban contradictions that the district has implied. In fact, the socio-spatial organisation of the district has generated a hybrid urban formation generally lacking in public spaces and characterised by a mixité of uses (Secchi, 1996).

Industrial firms gradually abandoned the area between the 1970s and the 1980s in a search for new locations in the outskirts, or were forced to close 
Figure 1. Macrolotto Zero in Prato (Italy)

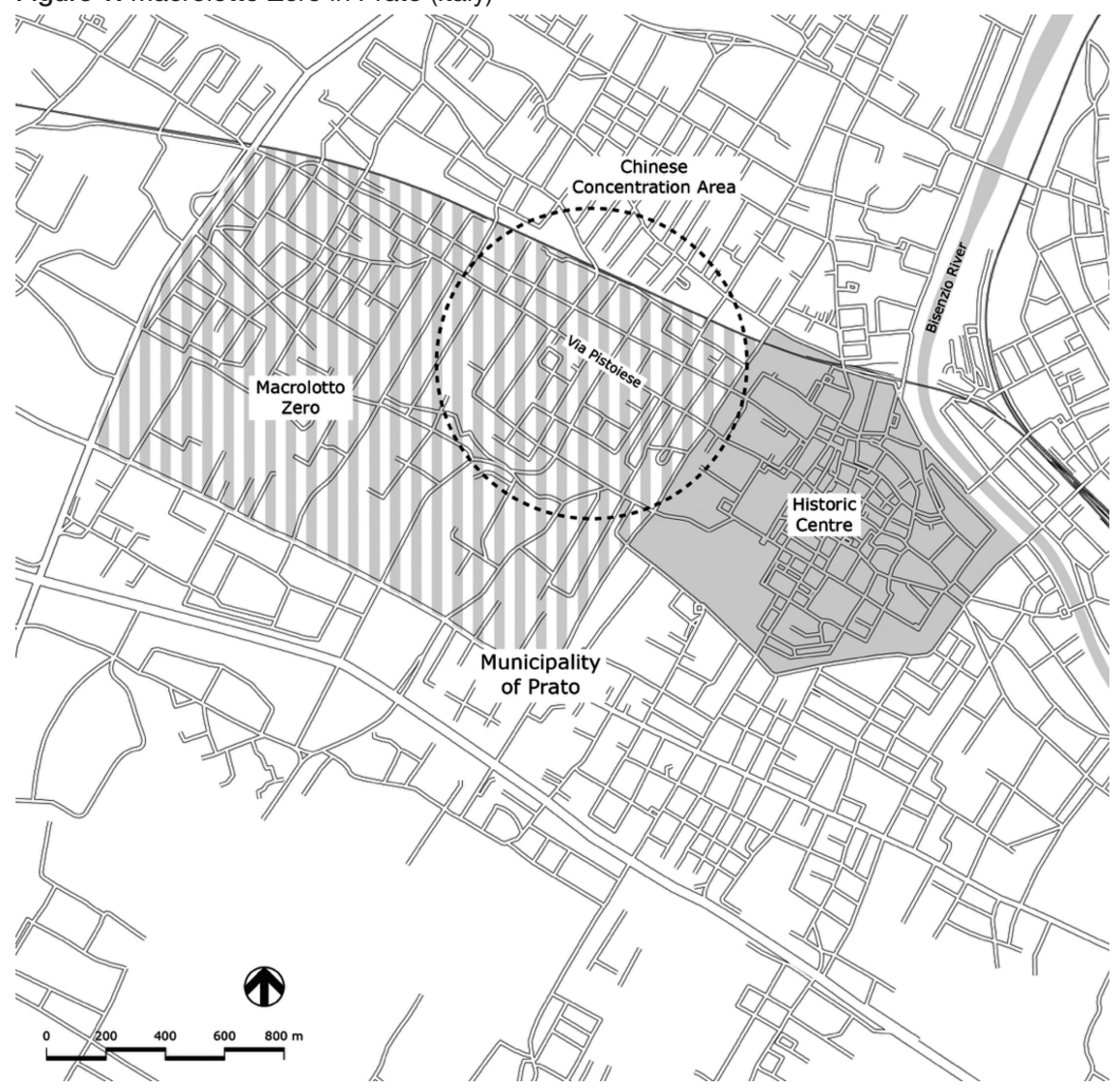

Source: Own elaboration.

due to the crisis of the traditional textile sector. The Chinese, during the reinitiation of large-scale migration had, by the beginning of the 1990s, found a suitable living and working environment in Prato, progressively filling the affordable vacant buildings. They successfully developed the garment industry, with the Chinese firms soon outnumbering the local ones. Those firms owned by Chinese reached quota 2,112 in 2010, amounting to $91.9 \%$ of the whole sector. ${ }^{1}$ Nowadays, the estimated Chinese population in Macrolotto Zero is just under $10 \%$ of the total.

SCdG belongs to the first metropolitan belt of Barcelona, featuring as a typical suburban city with a high rate of commuting and relatively easy access to more affordable housing. Together with the municipality of Badalo-

1. Source: Chamber of Commerce of Prato, <www.po.camcom.it>. 
Figure 2. Neighbourhood of Fondo in Santa Coloma de Gramenet (Spain)

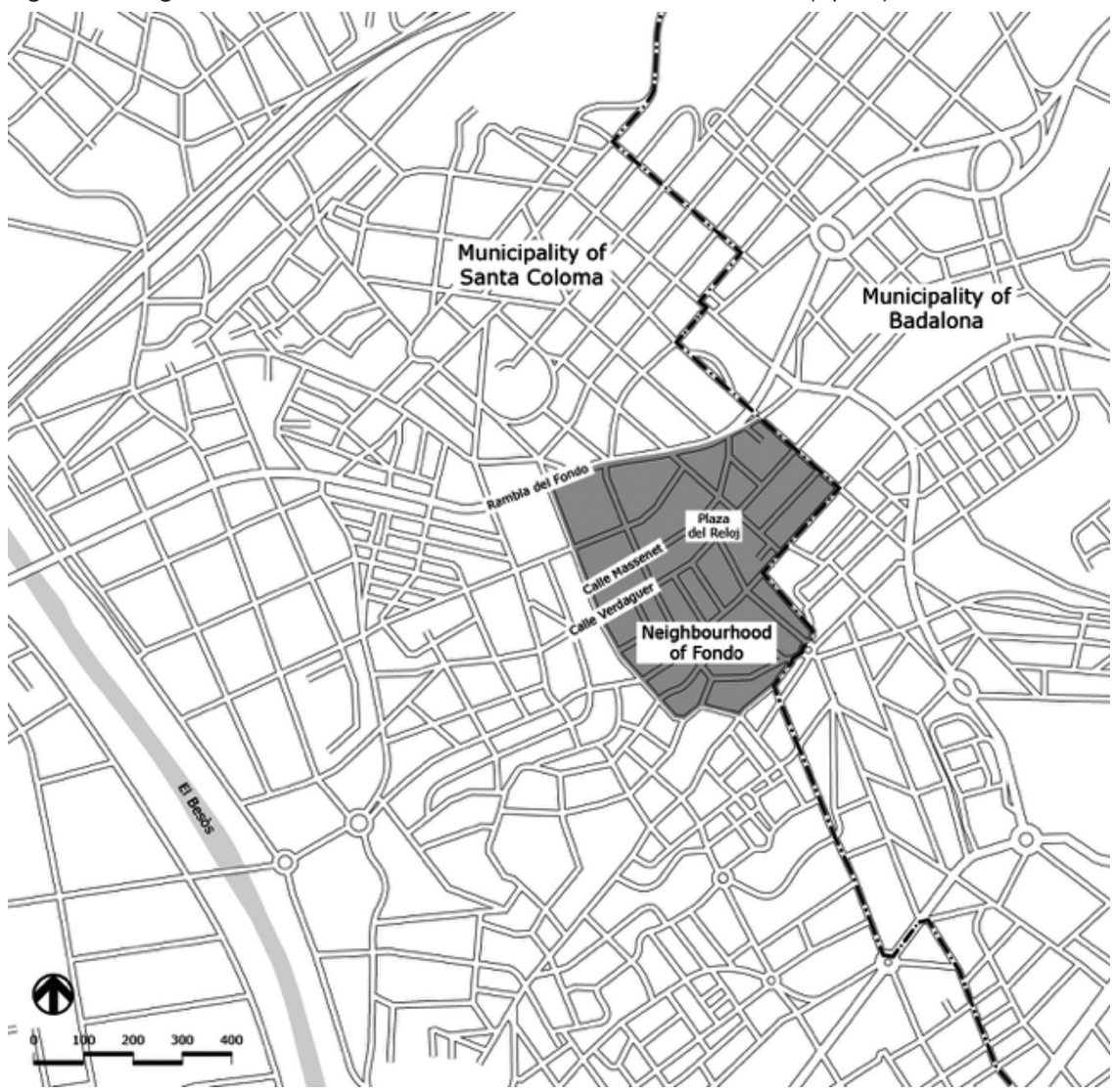

Source: Own elaboration.

na, which hosts another 3,680 Chinese, ${ }^{2}$ the Chinese population of the two cities reaches almost 8,500 in number. With a population of 2,503 Chinese, equating to almost $14 \%$ of the total neighbourhood, Fondo is the core area for Chinese migrants (Fig. 2).

Historically, SCdG and Badalona have followed the pattern of expansion of the metropolitan area of Barcelona, which was particularly impressive during the 1960s and the 1970s when they were turned from agricultural peri-urban areas into satellite cities. The whole north side of Barcelona has been attractive for domestic and then international migration. By the beginning of the 1990s, there was an unprecedented flow of Chinese migrants into this area, mainly to run ethnic restaurants or, especially in SCdG, to open small and,

2. Source: Instituto Nacional de Estadística (INE), 2011, <www.ine.es>. 
often, informal garment workshops (Beltrán Antolín and Sáiz Lòpez, 2003). As happened in Prato, Chinese migrants initially entered an already existing sector given the proximity with the 'Poligono Industrial de Montigala'; an industrial area with one of the largest concentrations of Catalan garment industries. More recently, the saturation of the catering sector, on the one hand, and the closure of several workshops due to violations of basic labour union standards, on the other, have contributed to the specialisation of Badalona in the wholesale and import sector of Chinese goods and of small retail activities in SCdG (Beltrán Antolín, 2009).

In contrast to Prato, fewer publications are available on SCdG and the assertions made regarding the location of the Chinese in Fondo are mainly based on the results of the interviews and direct observations performed during site visits. The centre of Chinese social life is the Plaça del Rellotge, a triangular square in the centre of Fondo densely characterised by ethnic retail. The nearby street Carrer Jacint Verdaguer specialises in restaurants and clothes, while Carrer Massanet street specialises in cheap technological devices and foodstuffs.

Prato and SCdG show similarities and, of course, differences. Prato is in fact one of the most important industrial districts of Italy, while SCdG is primarily a tertiary city strongly dependent upon Barcelona. According to Beltrán Antolín (2009), garment workshops still exist in SCdG but on a smaller scale than in Prato, which has, conversely, been able to scale up the business volume, even subcontracting to Italian firms or establishing international networks. Moreover, SCdG hosts almost 135 Chinese firms specialising in commerce and catering, becoming a retail centre for the whole of Catalonia. Both Beltrán Antolín (2005) and Bressan et al. (2008) argue, respectively for SCdG and Prato, that the two neighbourhoods have become important supra-local centres for the Chinese community.

The scale of the phenomenon has raised an issue of cohabitation between the newcomers and locals. According to a local officer in SCdG, 'the visual impact of the Chinese community is perceived as an invasion of the local community generating sometimes a feeling of opposition'. This is often merged with rumours related to the illegal management of the garment workshops, depicted by the media as sweatshops. Some of the rumours turn out to be true, as proved by the history of garment production (Ross, 2004) or by reports on the labour conditions of Chinese migrants (Gao, 2010), but the risk of misleading representations is ever present (Tarantino and Tosoni, 2009).

Moreover, in the case of Prato, it has been proved that the Chinese firms did not compete unfairly with Italian firms, at least in the initial stage of their arrival, but, on the contrary, ensured lower overall costs of the garment production chain, which was also beneficial for the Italian firms (Colombi et al., 2002; Dei Ottati, 2009). According to a local officer in Prato, 'the hostility of the local community toward the Chinese is a relatively recent phenomenon due to their irregular activities, perceived as the main cause of the textile sector crisis'. The rising levels of social conflict pushed the two municipalities to develop a series of measures to reduce the social tension and, at the same 
time, guarantee equal access to the basic local services. Meanwhile, a series of restrictions, codes and norms have been implemented to limit infringements regarding both the use of public spaces and the way of running retail activities. The two neighbourhoods were later designated as urban regeneration areas, as will be explained.

\section{Policies for social and cultural integration}

Two main government bodies have been in charge of the integration process: Servizio Immigrazione e Pari Opportunità (SIPO) in Prato and Servei de Convivència $(\mathrm{SdC})$ in SCdG. These governmental institutions have received financial support to study the migration phenomenon and to establish a liaison with the Chinese community, in particular with some specific associations. In some cases these associations have received the support of local government (co-financed projects, supply of spaces for meeting or working, etc.), in some others they have been ignored when not opposed. The SIPO was established in Prato in 1992. Since the very beginning, the goal was to offer a basic cultural mediation service and to collect data regarding migration, in collaboration with the University of Florence. In SCdG, the SdC carried out a similar role, cooperating with the Department of Geography of the Universitat Autonòma de Barcelona since 2005 to publish the Statistical Yearbook. This has given specific attention to migration by reporting the numbers of migrants and their location in the city for each ethnic group.

The two offices both provide a front desk with Mandarin-speaking staff in charge of residence permits, family reunions and language support. They are mostly tasked with providing translations, even in Prato where the Chinese community is more established. Both the SIPO in Prato and the SdC in SCdG provide a language and cultural mediation service with the intention of solving daily conflicts. The role of the mediator (generally bilingual) consists in listening to the reasons of each party trying to resolve the dispute before it escalates. According to the interviewees, the teaching service of Italian and Catalan languages is normally supplied by other agencies. A more critical issue is the absenteeism and drop-out rate among young students. In both cases, programmes are in place for continual support, although the interviewee suggested that it would be necessary to allocate more resources to these services in order to achieve improved outcomes. An important part of the integration policy is played by policies addressing women and young people (especially the second generations), such as employment orientation, healthcare, promotion of associations and, more broadly, cultural activities. These needs are becoming increasingly relevant as a consequence of the recent transformation of Chinese households. On the one hand, the number of family reunions has increased in recent years; but on the other hand, second generations are increasingly demanding integration.

Based on the interviewees' perception, this is surely a new phenomenon. In fact, the Chinese community is traditionally reluctant to be involved in the activities provided given that they can meet their needs within their own 
community. Moreover, the existing Chinese associations are normally businessoriented, seeking institutional and economic support from their countrymen, representing relatively small but powerful lobbies and no longer entirely representative of the new Chinese ethnic business landscape that has emerged (Ceccagno, 2007b). Particularly interesting are the new associations composed of second generation migrants, such as Associna and Young Group in Prato: the former is a national association with several delegations in Italy, whereas the latter is a Sino-Italian association for youths, in charge of organising sporting events, language classes, workshops, etc. In SCdG, the municipality has supported the establishment of the mixed association Fondo Commerc and the Asociación China-Catalana de promocion de la cultura popular, which, although not entirely representative of the Chinese community, are becoming a good channel of communication.

It is also worth mentioning the unique experience of the public library of SCdG (Can Peixauet). The library has created a specialised Library section in Chinese, making this organisation the most important Chinese library fund in Spain, with more than 8,000 volumes. At the present time, 54\% of the library users are foreigners, and most of these are Chinese. Although it did not reach the same size of Can Peixauet, the Biblioteca Comunale Lazzerini in Prato also regularly purchases foreign language books, proving an increasing demand for culture of the local Chinese community.

\section{Urban regeneration policies}

From the start, the spatial segregation of the two Chinese communities raised a concern related to the most appropriate spatial policies to apply and there has been a focus on regulation of those retail or industrial activities that are perceived as disturbing. The policy response is always either punitive (restriction of opening time, usage of local idiom, etc.) or educative (campaign for sharing best practice) targeting in primis the use of public space and the visual impact of ethnic activities (Fig. 3).

The common attitude of both cities was not to emphasise a picturesque image of Chinatown. In the case of Prato, this has never been demanded by the Chinese communities, while in the case of SCdG this has been asked and denied by the city's administration (McDonogh, 2013). Nevertheless, in both cities there are a variety of Chinese firms: some are ethnic-customer-oriented due to the very high residential concentration of Chinese, but some are expanding to any kind of shops, following a process of westernisation in place since the 1990s-early 2000s both in Italy and Spain. The retail activities of the two neighbourhoods of Macrolotto Zero in Prato and Fondo in SCdG share other common urban issues: they are historically characterised by migration and high population density, lack of quality public spaces and amenities, and obsolete housing. Migration clearly exacerbated an existing critical situation and the issue of the regeneration of both neighbourhoods soon became a priority for the two urban policies. Under the depicted scenario, the two cities launched two urban 
Figure 3. Chinese retail activities in Prato

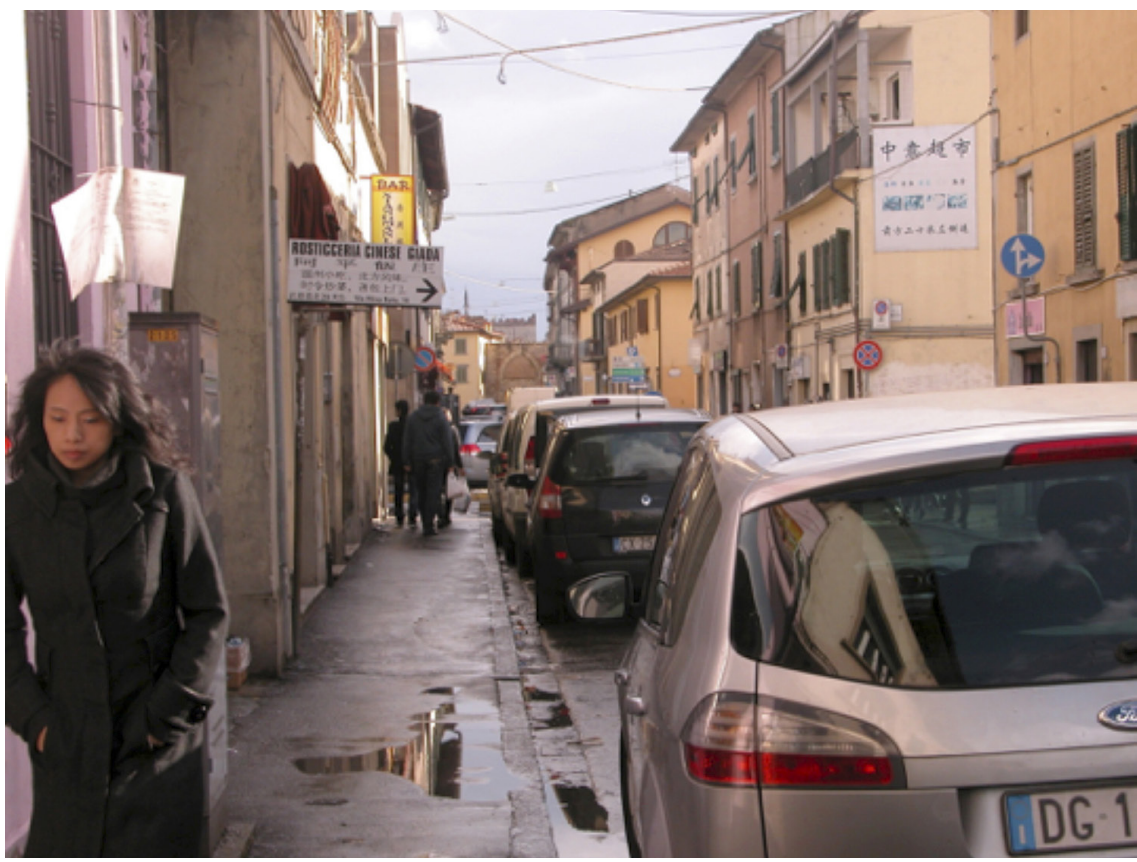

Source: Photo credit: Russo.

regeneration programmes: the so-called Progetto di riqualificazione del Macrolotto Zero in Prato and the Programa de Rehabilitación del Barrio de Fondo.

The Macrolotto Zero suffers from a long-lasting problem of abandoned industrial buildings. Although some of these have been rented to Chinese migrants, the general trend is the conversion from industrial to more profitable residential use. In the last decade the redevelopment happened without a comprehensive master plan, but was based on private-led speculative interventions. The result has often been scattered densification due to a conspicuous increase of the floor area ratio, with limited public benefits and lack of an organic vision of the city (Vannucchi, 2009). Aware of this situation, the City Council initiated a survey to identify the buildings worthy of conservation and adaptive reuse plus a feasibility study to employ transferable property rights mechanisms to reduce the density of the neighbourhood. A new local development plan (Piano Strutturale) was approved in 2012 defining a specific strategy of intervention for Macrolotto Zero (Gorelli, 2011). Later on, the municipality implemented the Master Plan for this area, defining a more detailed land use plan aimed at retaining the mixed productive and residential functions, and gradually introducing other advanced tertiary uses more compatible with the inner city area functions. Moreover, the plan designates new areas as public 
Figure 4. Plaza del Reloj in Santa Coloma de Gramenet

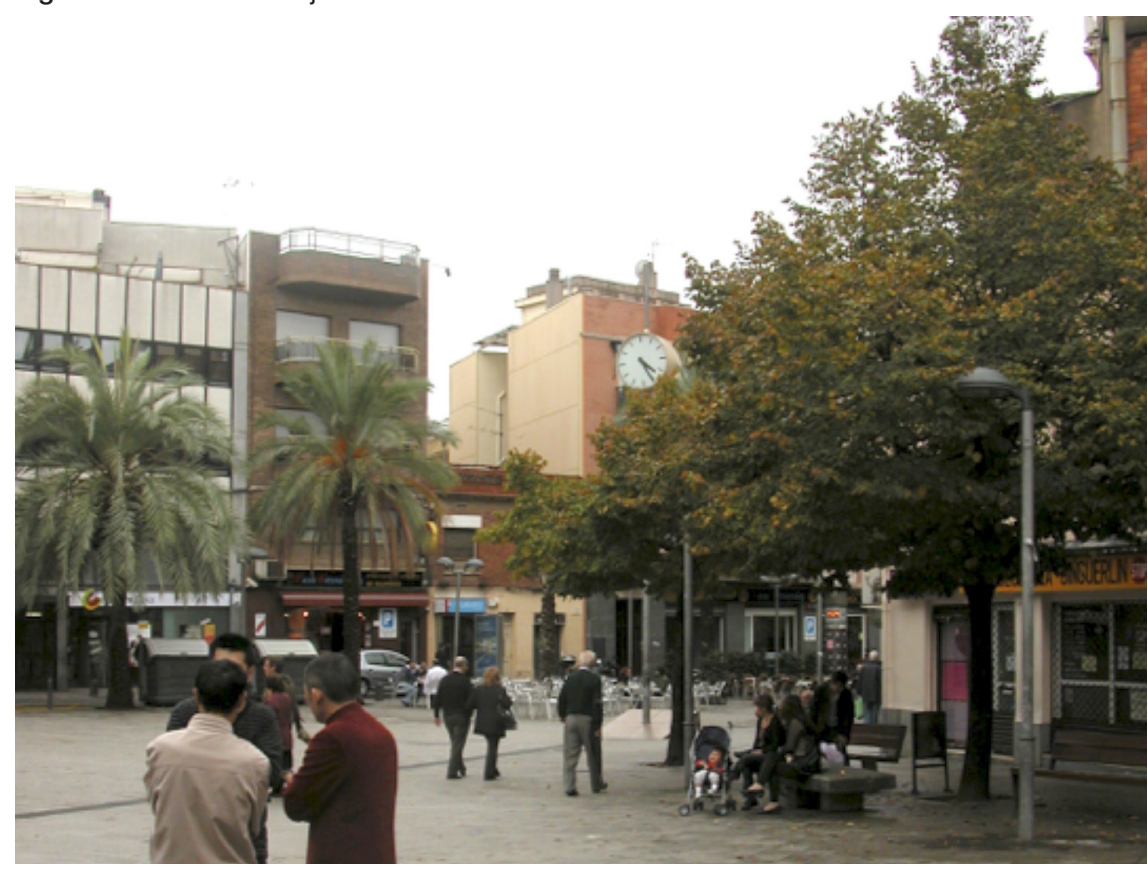

Source: Photo credit: Russo.

space and new pedestrian and cycle paths. The Chinese concentration area is designated to be partially suitable for punctual interventions of demolition with a contextual increasing of urban permeability. During the writing of the Master Plan, the City Council implemented a participatory process in collaboration with the University of Florence, which addressed the inclusion of marginal groups in an attempt to involve the Chinese community regarding the future of Macrolotto Zero (Paba and Perrone, 2009). The process ended with a town meeting, where a representative sample of citizens were asked to discuss and improve the draft of the Statuto del Territorio, the founding document of every Master Plan in Tuscany, introduced by the Regional Act 1/2005.

Fondo in SCdG was part of the Project d'Intervenció integral de la Serra d'en Mena, which included seven neighbourhoods belonging to SCdG and Badalona. The regeneration project started in 2005 with the economic contribution of the development fund (Fondo de Fomento) from the Generalitat de Catalunya through the Neighbourhood Act (Llei de Barris, 2002). The main goal of the Llei de Barris was the co-participation of the regional government in financing the regeneration of urban areas affected by the coexistence of some of the following problems: fabric obsolescence, demographic decline or overpressure, and social and economic deprivation (Fig. 4). 
As a typical area-based legislative tool, the Llei de Barris promoted the physical transformation of the neighbourhood, including the demolition of old buildings, opening of new roads and squares, provision of amenities and measures to support local economic development. The programme, which has been aptly named Fem Barri ('creating a neighbourhood' in Catalan), supported some of the social policies of SCdG. For instance, the Xarxa de transmissió de valors I missatges positius (literally, 'Positive Messages and Values Transmission Net'), a semi-public organisation in charge of promoting knowledge and awareness concerning migration and strategies for retail improvement, promoted bottom-up retail associations and the modernisation of retail activities. Fondo has surely been the neighbourhood that has taken most advantage of the fund, resulting in the transformation of Carrer Verdaguer into a pedestrian road, the redesign of Plaça del Rellotge and the flagship redevelopment of the old market (Mercat del Fondo) into a new multi-functional building hosting the new market, a shopping mall, a library and a kindergarten.

Within the programme Fem Barri, participation was facilitated all along the process, supervised by a monitoring committee with representatives from the state of Catalonia, the City Council of SCdG, neighbourhood representatives, economic stakeholders and grassroots citizen movements.

\section{Comparison and Discussion}

The cases presented here show the attempts of two municipalities in Southern Europe to deal with an unusually high concentration of migrants, in particular Chinese. The paper describes the social and spatial policies applied in the decade 2005-2015 in an attempt to understand whether the policy responses have effectively addressed the particular forms of clustering of the two Chinese communities. The peculiarity of the Chinese migration discussed here is partially detached from the traditional reproduction model of social exclusion within the capitalist system (Byrne, 1997). This should suggest that the same analytical lens should not be adopted although, very often, contemporary migration is associated with the typical urban problems of spatial exclusion such as poverty, unemployment, crime, etc. (Byrne, 2005). In fact, the Chinese community is highly entrepreneurial, relying on strong family and community networks finding, within the process of clustering, the condition for self-support and economic development that has elsewhere been referred to as 'good segregation' (Peach, 1996). As has been presented, their new urban formations differ from the stereotypical Chinatown, being interconnected through national or even transnational business networks, with potential benefits for the respective urban economy.

However, migration studies into the quickly mutating Chinese communities have clearly pointed out some negative aspects of such processes of clustering, which re-emerged in different forms from the 1990s in both contexts. As in other ethnic districts, their 'mixed embeddedness' has meant the entry into the lower end of the opportunity structure of the two urban contexts, allowing 
only small-scale, labour intensive and mainly low skilled activities (Kloosterman et al., 1999). The spreading of informality creates tensions between the locals and the migrants. On the other hand, it reproduces social marginalisation even within the same Chinese community. For example, the study on the vulnerability of Chinese migrants in the Veneto Region in Italy by Wu and Sheehan (2011) states that:

vulnerability $[\ldots]$ is related both to the poor working conditions in the ethnic economy and to workers' social isolation from local communities [...]. As a result, the contributions and voices of Chinese workers are not recognised by the public, nor do national or local migrant policies and services address their sufferings and needs in most circumstances. (p. 152)

Due to the high concentration of Chinese migrants, the issue of cohabitation has been included in the local policy agenda of both Prato and SCdG. The policy responses have addressed, in both cases, neighbourhood regeneration accompanied by a quite extensive range of policies for social and cultural integration, thus allowing a comparison of two municipal approaches with regard to the challenge of regenerating their respective 'Chinatown'.

The analysis in both cities has been pursued by looking at the local government response to the spatial and social issues highlighted, with particular attention to the way in which cities have engaged with local communities. This responds to the concern raised by Healey (2003) which emphasises the need to understand the role of social relational processes embedded in a specific place to cope with socio-spatial segregation. In summary, the research findings can be grouped around three main topics: government actions, forms of governance and relational resources that will be explained later in greater detail.

In terms of government actions, Prato and Santa Coloma have performed very actively, especially in the implementation of policies for migrants. The provision of services has partly followed the changing nature of the demand: from language services and cultural mediation, during the first migration phase, to more articulated cultural policies later. In general terms, they have been perceived as adequate, with some exceptions (continuous support), and gradually supplied by Chinese migrants along with their community development. An uncommon determination of institutional actors (see the cases of the two libraries, especially in SCdG) has uncovered hidden demands of sociocultural integration. Policies concerning urban regeneration have been enacted in both places although only SCdG has started a real process of physical transformation. In both cases, great emphasis has been placed on the improvement of the ethnic retail system: in Prato, mainly by imposing restrictions, while, in SCdG, by the additional support of dedicated funds for modernising existing shops or promoting bottom-up initiatives. In the last years, economic actors have been increasingly consulted and agreements have been signed both to enhance their business and to regularise informal jobs.

Concerning the forms of governance employed, during the implementation of the Urban Regeneration Project (SCdG) or during the revision of 
the planning instruments (Prato) forms of involvement of local communities have been employed. In both cases, they are provided to accomplish top down regional directives, namely the Llei de Barris of 2002 in Catalonia and the Legge Regionale n. 1/2005 in Tuscany. It is worth mentioning that in SCdG a supra-level monitoring system has ensured a fairer representativeness of actors.

Concerning the relational resources, in both cases, a rich associative landscape emerges, capable of establishing contacts with the two municipalities. In addition to economic lobbies, more open to dialogue, a variety of diverse and spontaneous associations are flourishing. In the case of SCdG, they demand access to culture (indicated also by the success of the library fund) but they are also persuaded to take part in retail associations, where there are dedicated funds to improve their activities. In the case of Prato, they are gradually moving from a purely opportunistic demand of economic interest protection to a more articulated demand of inclusion (especially women and young people).

Overall, two quite different approaches to urban regeneration have arisen, which have encountered some limitations in the process of involving the respective Chinese communities into the planning processes. In the case of Prato, despite efforts made to implement public participation and the willingness to involve the Chinese community of Macrolotto Zero, there is a lack of effective planning mechanisms to incorporate the results of the participatory process into the decision-making process (Paba and Perrone, 2010). This issue, which is partly related to the lack of maturity of such experiences in Southern Europe, has been tackled quite effectively by SCdG. The reason might be ascribable to the effectiveness of a project-based and more bottom-up approach under the guidance (and strong economic support) of an important exogenous (regional) funding programme, in contrast to a more traditional comprehensive planning approach. The planning process in Prato does not have any clear incentive to enlarge the democratic scope to a wider audience.

However, in both cases, although an important effort has been made in acknowledging the existing relational resources of the Chinese community, and the variety of voices within the same community, the urban regeneration programmes have not adequately addressed this diversity. In the case of Prato, urban regeneration has been seen as an opportunity to decongest the area of concentration of Chinese and, in the absence of real interventions, has been accompanied mainly by punitive measures to regulate the usage of public space. In the case of SCdG, urban regeneration has been an effective tool to change the image of the town, partially improving the retail sector, but without really supporting local requests (such as an arch and a cultural centre) to establish a more 'visible' Chinatown.

\section{Conclusion}

This paper has attempted to unveil the changing nature of two Chinese communities in Southern Europe inquiring whether the policies in place for urban regeneration and social integration in the decade 2005-2015 have been capable 
to capture this distinctive feature. This is based on the assumption that only a proper acknowledgment of the diversity of local community (in this case multicultural) can lead to sustainable and equitable outcomes in urban regeneration processes. As a matter of fact, the two municipalities have shown a remarkable effort in implementing policies for social integration but, at the same time, have partially failed to address holistically the issue of diversity in their respective urban regeneration policies. In the recent Report to the Parliamentary Assembly of the Council of Europe (2015) on 'Chinese migrations to Europe: Challenges and opportunities', the problem of integration is again reiterated. Some signs of change are also highlighted but these have primarily related to enhanced relationships and dialogue between Chinese communities and local civil society. It is a promising path witnessed in both cities (Ajuntament de Santa Coloma de Gramenet, 2015; Comune di Prato, 2016).

However, when it comes to physical interventions, clearly more politically sensitive, the still existing underlining tension and mistrust between communities does not yet allow embarking on more collaborative projects of urban regeneration. This is something that is already considered acceptable in cities such as in Northern European countries, where new Chinatowns might be instrumental to strengthen cultural and economic relationships between countries. It will probably be the challenge for the next decade of urban regeneration policies for countries of late migration in the south of Europe, but it will be likely depend on how local communities will evolve and also on which migrants these cities will be capable of attracting.

\section{Bibliographical references}

Ajuntament de Santa Coloma de Gramenet (2015). "El relat de la intervenció: construint la convivència 1995-2015”. Santa Coloma de Grament: Ajuntament. Available at:

<https://www.gramenet.cat/fileadmin/Files/Ajuntament/mediacio/documents/ El_relat_de_la_convivencia.pdf> (Accessed 31 October 2017).

Baldassar, L.; Johanson, G.; MCAuliffe, N. and Bressan, M. (eds.) (2015). Chinese Migration to Europe: Prato, Italy, and Beyond. London: Palgrave Macmillan.

BagnasCo, A. (1977). Tre Italie. La problematica territoriale dello sviluppo Italiano. Bologna: Il Mulino.

Baxter, L. and Woodland, G. (2005). The Friendship Arch: A Celebration of Shanghai and Liverpool. West Wirral, UK: 21st Century Cities.

Becattini, G. (2001). The Caterpillar and the Butterfly. An Exemplary Case of Development in the Italy of the Industrial Districts. Firenze: Felice Le Monnier.

Beltrán Antolín, J. (2000). Expansión geográfica y diversificación económica. Pautas y estrategias del asentamiento chino en España. Acta del II Congreso sobre la inmigración en España. Instituto Universitario de Estudio sobre Migraciones de la Universidad Pontificia Comillas - Instituto Universitario Ortega y Gasset, Madrid.

- (2005). "The seeds of Chinatown. Chinese Entrepreneurship in Spain". In: E. SpaAn, F. Hillmann and T. Van Naersen (eds.). Asian Migrants on the European Labour Markets. London: Routledge, 285-308. 
- (2009). “La inmigración china en Cataluña”. In: J. Julià-Muné (ed.). Visions de la Xina: cultura multimil.lenària. Lleida: Institut d'Estudis Ilerdencs de la Diputació de Lleida, 125-150.

Beltrán Antolín, J. and SÁiz López, A. (2003). "Trabajadores y empresarios chinos en Cataluña”. Paper presented at the IV Congrés Català de Sociologia, Reus.

Beraha, R. (2012). La Chine à Paris : Enquête au coeur d'un monde méconnu. Paris: Robert Laffont.

BERTHOud, R. (2000). "Ethnic employment penalties in Britain". Journal of Ethnic and Migration Studies, 26 (3), 389-416. <https://doi.org/10.1080/713680490>

BRESSAN, M.; FANFANI, D. and RADINI, M. (2008). "Prato dalla citta fabbrica alla societa multiculturale. Analisi di alcune dimensioni dell'abitare periferico". In: L. Fregolent (ed.). Periferia e periferie. Roma: Aracne, 334-379.

BriatA, P. (2013). "Conflitti, risorse e politiche territorali nella Chinatown di Milano". Archivio di Studi Urbani e Regionali, 106, 134-141. <https://doi.org/10.3280/ASUR2013-106012>

BYRNE, D. (1997). "Social exclusion and capitalism: The reserve army across time and space”. Critical Social Policy, 17 (1), 27-51. <https://doi.org/10.1177/026101839701705002>

- (2005). Social exclusion. Maidenhead, Berkshire: Open University Press.

CASTELLS, M. (1989). The informational city. Information technology, economic restructuring and the urban-regional process. Oxford: Basil Blackwell.

Ceccagno, A. (2003). "New Chinese migrant in Italy". International Migration, 41 (3), 87-213. <https://doi.org/10.1111/1468-2435.00246>

- (2007a). "The Chinese in Italy at a crossroad: The economic crisis". In: M. THunØ, (ed.). Beyond Chinatown: New Chinese migration and the global expansion of China. Copenhagen: Nias Press, 115-136.

- (2007b). "Compressing personal time: ethnicity and gender within a Chinese niche in Italy". Journal of Ethnic and Migration Studies, 33 (4), 635-654.

CHEN, C. (2013). "Migration, production networks, and identity politics in Europe: Chinese immigrant communities in Italy and Spain". Working paper presented at the Comparative Politics Workshop of Political Science Department. University of Pennsylvania.

Colombi, M.; Guercini, S. And Marsden, A. (eds.) (2002). L'imprenditoria cinese nel distretto industriale di Prato. Firenze: Olschki.

Comune di Prato (2016). Percorso per la definizione di interventi prioritari e relative prospettive di finanziabilità in tema di politiche di integrazione. Prato: Comune di Prato. Available at: <http://www2.comune.prato.it/partecipazione-integrazione/ pagina 485.html $>$ (Accessed 31 October 2017).

Council of Europe (2015). Chinese migration to Europe: challenges and opportunities. Report of the Committee on Migration, Refugees and Displaced Persons. Bruxelles: Council of Europe. Available at: <http://assembly.coe.int/nw/xml/ XRef/Xref-DocDetails-EN.asp?fileid=21768\&lang=EN> (Accessed 31 October 2017).

Dei OtтAті, G. (2009). "An Industrial District Facing the Challenges of Globalization: Prato Today”. European Planning Studies, 17 (12), 1817-1835. $<$ https://doi.org/10.1080/09654310903322322>

Fainstein, S. (2010). The Just City. Ithaca, NY: Cornell University Press. 
Forester, J. (1989). Planning in the Face of Power. Berkeley, CA: University of California Press.

Friedman, J. (1995). "Migrants, civil society and the New Europe: The challenge for planners". European Planning Studies, 3 (3), 275-285. <https://doi.org/10.1080/09654319508720307>

GaO, Y. (ed.) (2010). Concealed Chains: Labour Exploitation and Chinese Migrants in Europe. Geneva: International Labour Organization.

GORELLI G. (2011). "Rigenerazione urbana: strategia fondamentale del nuovo Piano Strutturale di Prato". Urbanistica, 146, 7-13.

Healey, P. (1997). Collaborative Planning: Shaping Places in Fragmented Societies. Vancouver: University of British Columbia Press. <https://doi.org/10.1007/978-1-349-25538-2>

- (1998). "Building institutional capacity through collaborative approaches to urban planning". Environment and Planning: A, 30 (9), 1531-1546. <https://doi.org/10.1068/a301531>

- (2003). "Institutionalist theory, social exclusion and governance". In: A. MADANIpOur, G. CARS and J. Allen (eds.). Social Exclusion in European Cities. Processes, Experiences and Responses. New York - London: Routledge.

Jones, P. and Evans, J. (2008). Urban Regeneration in the UK. London: Sage.

Kloosterman, R., Van Der Leun, J. and Rath, J. (1999). "Mixed Embeddedness: (In)formal Economic Activities and Immigrant Businesses in the Netherlands". International Journal of Urban and Regional Research, 23, 252-266.

KunZmAnN, K. R. (2008). "The implications of rapid economic growth in China for spatial development in metropolitan city-regions". Town Planning Review, 79 (2-3), 331-346. $<$ https://doi.org/10.3828/tpr.79.2-3.9>

Mingione, E. (2009). "Family, welfare and districts. The local impact of new migrants in Italy". European Urban and Regional Studies, 16 (3), 225-236. <https://doi.org/10.1177/0969776409104690>

McCarthy, J. (2007). Partnership, Collaborative Planning and Urban Regeneration. Farnhem: Ashgate.

McDonogh, G. W. (2013). "Chinatowns: Heterotopic space, urban conflict, and global meaning”. Quaderns-e, 18, 96-111.

NieTO, G. (2003). “The Chinese in Spain”. International Migration, 41 (3), 215-237. $<$ https://doi.org/10.1111/1468-2435.00247>

Paba, G. And Perrone, C. (2009). Progettare insieme la città, Report Conclusivo. <http://allegati.comune.prato.it/dl/20110111095531344/report-unifi.pdf> [consulted: 23rd June 2016]

- (2010). "Le sfide della pianificazione partecipata: dilemmi della teoria, tranelli delle pratiche. Il caso di Prato". Paper presented at the SIU XIII Conference "Città e crisi globale", Roma.

PEACH, C. (1996). “Good segregation, bad segregation”. Planning perspectives, 11 (4), 379-398. <https://doi.org/10.1080/026654396364817>

Pieke, F. N. (2002). Recent Trends in Chinese Migration to Europe: Fujianese Migration in Perspective. Geneva: IOM International Organization for Migration.

Ribas-Mateos, N. (2004). "How can we understand immigration in Southern Europe?". Journal of Ethnic and Migration Studies, 30 (6), 1045-1063. <https://doi.org/10.1080/1369183042000286241> 
Roberts, P. (2000). "The evolution, definition and purpose of urban regeneration". In: P. RoberTs, and H. SyKes (eds.). Urban Regeneration. A Handbook. London: Sage.

Ross, R. J. S. (2004). Slaves to Fashion: Poverty and Abuse in the New Sweatshops. Ann Arbor: University of Michigan Press.

SaHin, M; NijkamP, P. AND StOUgh, R. (2009). "Impact of urban conditions on firm performance of migrant entrepreneurs: a comparative Dutch-US study". Annals of Regional Science, 46 (3), 661-689. <https://doi.org/10.1007/s00168-009-0351-2>

SECCHI, B. (1996). Un progetto per Prato. Firenze: Alinea.

SKeldon, R. (1997). Migration and Development: A Global Perspective. London: Longman.

TAllon, A. (2010). Urban Regeneration in the UK. London - New York: Routledge.

Tarantino, M. and Tosoni, S. (2009). "The Battle of Milan: Social Representations of the April 2007 Riots by Two Chinese Communities”. In: G. JoHANSON, R. SMYTH and R. French (eds.). Living Outside the Walls: The Chinese in Prato. Cambridge: Cambridge Scholars Press, 202-219.

Thunø, M. (eds.) (2007). Beyond Chinatown: New Chinese Migration and the Global Expansion of China. Copenhagen: Nias Press.

Umemoto, K. and Igarashi, H. (2009). "Deliberative Planning in a Multicultural Milieu”. Journal of Planning Education and Research, 29 (1), 39-53. $<$ https://doi.org/10.1177/0739456X09338160>

Vannucchi, P. M. (ed.) (2009). Prato e il tema delle aree miste. Siena: Lalli Editore.

VERDINI, G. (2011). "Rise, fragmentation, infringement and fear: emerging urban issues in Chinese clustering in Italy”. In: A. Gonzalez Brun, B. L. Low, J. RosEMANN and J. WIDODO (eds.). Global Visions: Risks and Opportunities for the Urban Planet. Singapore: Centre for Advanced Studies in Architecture, 245-256.

Wong, B. (1988). Patronage, Brokerage, Entrepreneurship and the Chinese Community of New York. New York: AMS Press.

Wu, B. and SHEEHAN, J. (2011). "Globalization and vulnerability of Chinese migrant workers in Italy: Empirical evidence on working conditions and their consequences". Journal of Contemporary China, 20 (68), 135-152. $<$ https://doi.org/10.1080/10670564.2011.520852> 